V.Zarosyloㅁ, Dr. Sc. (Jurid.), Prof., orcid.org/0000-0001-6935-5449, O. Fatkhutdinova ${ }^{2}$, Dr. Sc. (Philos.), Prof., orcid.org/0000-0001-8990-0950,

T. Morozovska ${ }^{1}$, Cand. Sc. (Jurid.), Assoc. Prof., orcid.org/0000-0002-7906-2583,

T. Arifkhodzhaieva ${ }^{1}$, Cand. Sc. (Jurid.), Assoc. Prof., orcid.org/0000-0002-1827-1699,

H. Strohanova ${ }^{3}$, Cand. Sc. (Pedag.), Assoc. Prof., orcid.org/0000-0003-2900-3152
1 - Interregional Academy of Personnel Management, Kyiv, Ukraine, e-mail: zarosi@ukr.net

2 - Kyiv University of Tourism, Economics and Law, Kyiv, Ukraine

3 - National Pedagogical Dragomanov University, Kyiv, Ukraine

\title{
LEGAL REGULATION OF OCCUPATIONAL SAFETY AND HEALTH IN THE EUROPEAN UNION AND UKRAINE: A COMPARATIVE APPROACH
}

Purpose. To use the comparative approach to study the compliance of legal regulation of labor protection in the European Union and Ukraine, as well as on the basis of the results to formulate a strategy for the development of the legislative framework for labor protection in Ukraine.

Methodology. The authors built their research on the possibilities of the comparative approach. Two principles were used as the main ones: a) the principle of comparability of the phenomena, institutions and departments; b) the principle of correspondence between different levels, forms and types of elements of the compared systems.

Findings. The authors considered the possibility of a comparative approach, by which they compared the meanings of the term "labor protection" in Ukraine and the European Union. The authors proved their inconsistency, as well as the need to abandon the use of the term "labor protection" in favor of the term "occupational safety and health", which is used in laws and regulatory documents of the European Union. The authors formulated the main directions of the new strategy of legal regulation of labor protection in Ukraine.

Originality. The use of a comparative approach when considering the compliance of legal regulation of occupational safety and health in the European Union and Ukraine allowed:

1. Proving the need to replace the term "labor protection" with the term "Occupational safety and health" which is used in laws and regulations of the European Union.

2. Formulating a strategy for the development of the legislative framework for occupational safety and health in Ukraine for its adaptation to the fundamental principles legalized by the European Parliament.

Practical value. The results of the study develop the legislative framework for labor protection in Ukraine, as well as adapt it to key directives, guidelines and standards of the European Union, the United Nations, the World Health Organization, the International Labour Organization and other authoritative international organizations and institutions. The study eliminates the legal conflict existing in the Ukrainian legislation on labor protection, which violates the work of the legal system and infringes on the rights of citizens.

Keywords: labor protection, occupational safety and health, legal regulation, Ukraine, European Union, comparative approach, legal education

Introduction. Since 2014, The United Nations has been issuing annual reports: "Global report on sustainable development" [1]. The main objective of the publications is to strengthen the interaction between science and practice with a view to 2030. The reports make it possible to coordinate the public administration of 193 States, which are currently members of the $\mathrm{UN}$, in the direction of sustainable development of society.

An important place in the reports is hold by the theme of "labor protection". The authors of the article paid their attention to the discrepancy between the meaning of the term "labor protection" and the difference in the legal regulation of labor protection in the European Union and Ukraine. In Ukraine, in the sense of the term "labor protection", as well as in the adopted standards, laws and regulatory documents, there continues to be seen inconsistency, inconsistency of concepts and ambiguity of wording.

In view of the fact that Ukraine has chosen the path of integration into the European Union, there is a need to adapt Ukrainian laws and regulations under the key directives, guidelines and standards of the European Union, which in turn are consistent with the principles of the United Nations, the World Health Organization, the International Labour Organization, as well as other authoritative international organizations and institutions. In this regard, the principle described

(C) Zarosylo V., Fatkhutdinova O., Morozovska T., Arifkhodzhaieva T., Strohanova H., 2019 in the 2016 global Sustainable Development Report is particularly relevant: "Ensuring that no one is left behind" [1].

In the article, the authors use the opportunities of the comparative approach to the study of the compliance of the legal regulation of occupational safety and health in the member States of the European Union and Ukraine.

Results. Legislative regulation of occupational safety and health in the European Union is based on the relationship and interaction of European, international and national law. The complex legal framework of occupational safety and health most fully reveals its functionality and efficiency, when we use a comparative approach as the main method of knowledge. The comparative approach is based on two main principles:

1. The principle of comparability of phenomena, institutions and establishments.

2. The principle of matching different levels, forms and types of elements of the compared systems.

The latter principle is always interpreted broadly, and includes many other, secondary in importance principles. For example, the principle of taking into account historical, national, economic, socio-political and other conditions in which the compared legal systems arise and develop; the principle of establishing not only the General features and characteristics of the compared legal systems, but also their features; etc. (for example [2]).

The possibilities of the comparative approach allow not only comparing the features of the legal regulation of occupa- 
tional safety and health in the European Union. The comparative approach allows comparing legal systems to establish General principles and approaches to occupational safety and health in States with a different history of law and socio-economic systems. It is on the basis of these principles that the European Parliament has developed and adopted uniform directives for all States of the European Union, which are legally binding and are taken into account in the development of the national legislative systems of the Member States of the European Union.

The comparative approach will allow us to compare the basic meanings and legal basis of occupational safety and health in Ukraine and the States of the European Union. Based on the results, we will formulate a strategy for the development of the legislative framework for occupational safety and health in Ukraine for its adaptation to the fundamental principles legalized by the European Parliament

Our analysis begins with a comparison of the meaning of the terms "labor protection" and "occupational safety and health" in Ukraine and the European Union.

The Law of Ukraine "Pro okhoronu pratsi" [On Labour Protection] in Article 1 provides the following definition: "okhorona pratsi [labour protection] is a system of legal, socio-economic, organizational and technical, sanitary and hygienic, medical and preventive measures and means aimed at preserving the life, health and working capacity of a person in the course of employment" [3].

The literal translation into English of the term "okhorona pratsi" sounds like "Labor protection." Almost all Ukrainian authors who study "okhorona pratsi" as a scientific problem use this term when translating their works into English. However, in fact, in English, the term "Labor protection" has a different meaning. This value is disclosed, for example, in the articles "Labor Protection and Leverage" [4] or "Labor protection and the privatization or partial privatization method" [5]. The term "Labor protection" has a literal meaning: "employment protection in the labor market". Thus, in the first article, the authors prove that labor protection as the protection of employment by the state begins to replace the financial levers of influence on employment [4]. In the second article, the authors consider "Labor protection" as a degree of legal protection of the labor force in the privatization of state-owned enterprises through share issues in the public stock exchange or through asset sales to a small group of investors [5].

In the legal documents of the European Union, the meanings of the term "okhorona pratsi", which are used in Ukrainian legislation, are mostly transmitted in the term "Occupational safety and health". In the Ukrainian language, the term "bezpeka i hihiiena pratsi" is synonymous with this term.

The term "occupational safety and health" is quite often used in the Ukrainian legal system. However, as noted by Ukrainian researcher S. Voloshyna: "In the science of labor law it is recognized that the norms on safety and health at work belong to the Institute of labor protection" [6]. In fact, the legal norms of occupational safety and health, which substantially include technical and sanitary standards, are an integral part of the Institute of "labor protection" of individual labor law.

Ukrainian legislation on "occupational safety and health" consists of three complementary laws that provide legal regulation on the basis of the meanings contained in the term "okhorona pratsi" ("labour protection"). First of all, it is the Law of Ukraine "On labor protection" [3], and:

1. Code of Labour Laws of Ukraine [7].

2. The law of Ukraine "On compulsory state social insurance against industrial accidents and occupational diseases that caused disability" [8].

The integration of Ukraine into the European space implies the change in Ukrainian legislation under the legislation of the European Union. In this case, Ukrainian lawyers will have to change the meaning of the term "okhorona pratsi", which is decisive in the legislation of Ukraine. It will be necessary either to equalize the meaning of the terms "okhorona pratsi" and "occupational safety and health", or to abandon the use of the term "okhorona pratsi" in favor of the term "occupational safety and health" ("bezpeka i hihiiena pratsi"), which is used in the laws and regulations of the European Union.

Dreval Yu. in the article "Problems of conceptual and categorical apparatus in the field of labor protection", which was written in 2018, compares the meanings of the terms "labor protection", "labor safety" and "occupational safety and health", as well as the features of their use in the legal field of Ukraine [9]. Currently, all three terms are actively used in Ukrainian laws and regulations. Due to the fact that each of the terms carries a different meaning, a legal conflict arises that weakens the possibility of legal regulation of labor protection in Ukraine. Consider two important conclusions for our study, to which Yu. Dreval came [9].

First, Dreval noted that in the legal literature over the past few years, the term "labor protection" has been used much less frequently, while Ukrainian lawyers began to use the term "occupational safety and health" much more often. As a result of the analysis, Dreval expressed his disagreement with the conclusions of S. Voloshyna, which we reported earlier. Dreval writes that "the analysis of the provisions of international instruments gives grounds for the conclusion that the concepts of "labor protection" and "occupational safety and health" are not significantly different" [9]. That is, in fact, Dreval recognizes the gradual replacement of the term "okhorona pratsi" ("labor protection") with the term "bezpeka i hihiiena pratsi" ("occupational safety and health"), which is actively used in the English legal literature. This is not surprising. Any study on "okhorona pratsi" that goes beyond the study of legal literature of the CIS countries faces the problem of compatibility of terminology. In legal documents of the United Nations, the International Labour Organization, the European Union and other authoritative international organizations the term "okhorona pratsi" ("labour protection") is not used, or if being used, it has a narrow, literal context. However, the meanings that Ukrainian lawyers put into the term "okhorona pratsi" (labor protection) in the key documents of all leading international organizations are necessarily considered and discussed, though under the second term of "occupational safety and health".

Secondly, Dreval states the inconsistency of the Ukrainian legislative framework on occupational safety and health. For example, in the Constitution of Ukraine, in Article 43 it is written "Everyone has the right to appropriate, safe and healthy working conditions, to the salary which is not lower from the determined by the law" [10]. The term "safe and healthy working conditions" is found in the Law of Ukraine "On approval of the National social program to improve safety, health and working environment for 2014-2018" [11]. However, neither of these two laws defines the term "safe and healthy working conditions". But more importantly, the term itself is not used in the Laws of Ukraine: "On Labor Protection" [3], "Code of Labor Laws of Ukraine" [7] and "On compulsory state social insurance against industrial accidents and occupational diseases that have caused disability" [8]. We can, of course, assume that the term "safe and healthy working conditions" is synonymous with the term "labor safety", which is stipulated in these laws. However, in the term "safe and healthy working conditions" there is a word "conditions", which actually leaves without attention the role of "employee" in ensuring occupational safety and health in the workplace. Only the employer can create "conditions". Therefore, the term "safe and healthy working conditions" reveals the role of only one of the two subjects of labor protection policy, namely, the employer. Thus, the terms "safe and healthy working conditions", "labor safety" and "labor protection", which are the main definitions in the laws of Ukraine on occupational safety 
and health, are not synonymous, but bear different semantic load. This creates a legal conflict that violates the work of the legal system, infringes on the rights of citizens, as well as produces abuse in public authorities.

Thus, the comparison of the meaning of the terms "labor protection" and "occupational safety and health" in Ukraine and the European Union puts us before the fact of the need to replace the term "okhorona pratsi" ("labor protection") with the term "bezpeka i hihiiena pratsi" ("occupational safety and health").

How appropriate is this replacement? After all, in fact it means large-scale changes in the legislative framework of Ukraine. Dreval himself, despite his established key role of the term "Occupational safety and health" in international legal instruments on labor protection comes to a different conclusion. He writes that "given that the concept of "labor protection" is explained in a special law and is widely used in occupational health practice, the priority should be given to this concept" [9].

In articles by G. Smirnov [12], S. Rudenko [13], O. Kyvliuk [14] and many others, the authors came to the following two conclusions:

1. Consideration of any area of activity should begin with the development of a strategy. The lack of a development strategy reduces any activity to regression.

2. The development strategies of Ukraine should take into account the course of European integration. The course of Ukraine's accession to NATO and the European Union is enshrined in the Constitution of Ukraine. It is legally binding.

Ukraine's course towards European and Euro-Atlantic integration gives us the right to assert the need to replace the term "okhorona pratsi" ("labor protection") with the term "bezpeka i hihiiena pratsi" ("occupational safety and health"). This replacement is due to the strategic benefit to the legislation of Ukraine. On the one hand, the introduction of the term "occupational safety and health" will eliminate contradictions within the Ukrainian legal framework; on the other hand, it will organize the legal regulation of occupational safety and health in Ukraine at the level of international and European standards.

The introduction of a single and defining term "occupational safety and health" into the legislative base of Ukraine allows formulating a new strategy for the development of legal regulation of occupational safety and health in Ukraine. Let us formulate its main directions.

The first direction, the use of legal regulation of occupational safety and health in the European Union to improve their own legislation. Changing the Ukrainian legislation to the meaning of the term "occupational safety and health" allows borrowing the key principles of occupational safety and health of the European Union, which have proved their effectiveness in the work of the European legal system. Note that in 1994 the European Union was created by European Agency for Safety and Health at Work (EU-OSHA) [15]. The Agency's activities are carried out in two main areas:

1. Collection, analysis and dissemination within the European Union of information relating to safety and health at work. The Agency publishes a monthly newsletter that addresses current issues that improve occupational safety and health across Europe and the world [15].

2. Database creation on occupational safety and health for policy makers. This framework allows European politicians to form a strategy for the development of occupational safety and health, as well as monitor the implementation of daily tasks aimed at the development of occupational safety and health in the European Union and in the territory of their States.

The website of the European Agency for Safety and Health at Work presents the legislative framework on the basis of which the legal regulation of Occupational safety and health in the European Union is carried out. This is primarily the European Directives, which have legal force in all States of the European Union. In accordance with these directives, the legis- lation of the States applying for accession to the European Union is mandatory, including the legislation of Ukraine. European directives establish two basic principles of legal regulation of Occupational safety and health [15]:

1. The principle of prevention and risk assessment.

2. The responsibilities of employers and employees.

European Union directives form the EU guidelines as well as EU standards on Occupational safety and health. The guidelines and standards of the European Union define the national legislation of the States of the European Union, as well as their national strategies for the development of legal regulation of labor protection. The integration and coordination of national policies is the first of the seven key strategic objectives contained in the Strategic framework of the EU Strategic Framework on Health and Safety at Work 2014-2020 [16].

The second direction is the use of the possibilities of legal regulation of occupational safety and health by authoritative international organizations. We are talking about standards, norms and legally binding documents of such organizations as:

1. The International Labour Organization (ILO), which sets international heads of the management system of occupational safety (OSH management systems). ILO is a United Nations Agency. It promotes social justice and decent work [17]. International labor standards are seen as an integrated system of work and social policy instruments, supported by a system of supervision designed to address all kinds of problems when applied at the national level.

2. The World Health Organization (WHO), which is a specialized agency of the United Nations [18]. It is this organization that sets health and safety standards that are legally binding on States that are members of the United Nations.

These and other international organizations generate the main ideas, meanings and strategies on the basis of which laws and regulations are formulated that ensure highly effective legal regulation of occupational safety and health. In the world legal literature, the term "occupational safety and health" has synonyms: "occupational health and safety (OHS)", "occupational health" or "workplace health and safety" (WHS).

The third direction is the introduction of innovative legal training. Among the tasks of technology development by 2030, which are formulated in the "Global Sustainable Development Report", are the following [1]:

1. Continuous improvement in the production and consumption of global resources and economic growth without environmental degradation.

2. Achieving higher levels of economic efficiency through diversification, technological improvement and innovation.

3. Upgrading infrastructure and production facilities to make them sustainable, improving resource efficiency and expanding the introduction of environmentally friendly technologies and production processes.

The implementation of these tasks can only provide the introduction of innovative technologies in the educational system. The need for the introduction of new technologies in the Ukrainian education, based on the achievements of neuroscience, neuropsychology, neuroprogramming technologies, etc., is justified in the studies of O. Bazaluk [19], O. Khyzhna [20], Yu. Lavrysh [21], D. Svyrydenko [22], and others. The whole complex of innovative technologies, which is considered by the above authors, provides a meaningful change in the Ukrainian legal education. Legal education begins to exert its influence from an early age. It manifests its potential with educational work in schools, when young students begin to be taught the highest possible levels of health, which are provided by the objectives of the World Health Organization [18], as well as talk about the prohibition of child labor, the difference between forced and compulsory labor, in other principles adopted in the "Declaration on Fundamental Principles and Rights at Work" [17].

Innovative legal training is intensively developed in the States of the European Union and supported at the state level. It allows 
not only teaching the younger generation the principles, practices and theory of law from an early age, but also forming a legal culture in which occupational safety and health is an important part.

The fourth direction, the consolidation in the legal field of Ukraine, as well as the strengthening of the role of non-governmental organizations that are responsible for: a) the promotion, regulation and verification of compliance with legislation on safety and health; b) research, training, publication and information in the field of occupational safety and health. We are talking about industrial associations, trade unions, bar associations that specialize in the field of occupational safety and health, etc.

Conclusions. Thus, the authors considered the possibilities of a comparative approach in order to use them to compare the meanings of the terms "okhorona pratsi" ("labor protection") and "bezpeka i hihiiena pratsi" ("occupational safety and health") in Ukraine and the European Union. The analysis carried out by the authors found a discrepancy between the meaning of the term "okhorona pratsi" ("labor protection"), which is the main and defining in the legal field of Ukraine, the meaning of the term "bezpeka i hihiiena pratsi" ("occupational safety and health"), which is used in the laws and regulations of the European Union. The authors proved the need to replace the term "okhorona pratsi" with the term "bezpeka i hihiiena pratsi". Using "occupational safety and health" as the only and defining term in the Ukrainian legislation allowed the authors to formulate four main directions of the strategy of legal regulation of occupational safety and health in Ukraine:

1. Using the possibilities of legal regulation of occupational safety and health in the European Union to improve its own legislation.

2. Using the possibilities of legal regulation of occupational safety and health the International Labour Organization (ILO) and the World Health Organization (WHO).

3. Introduction of innovative legal training.

4. Consolidation in the legal field of Ukraine, as well as strengthening the role of non-governmental organizations that are responsible for: a) promoting, regulating and verifying compliance with the requirements of legislative acts on occupational safety and health; b) conducting research, training, publishing and informing in the field of occupational safety and health.

\section{References.}

1. Global Sustainable Development Report (2016). Retrieved from https://sustainabledevelopment.un.org/globalsdreport/. 2. Deryabina, Ye.M. (2019). European law: questions of the theory and methodology of cognition. Monograph. Prospekt.

3. The Law of Ukraine "On Labor Protection" (2018). New version of January 20, 2018. Retrieved from https://zakon.rada. gov.ua/laws/show/2694-12.

4. Simintzi, E., Vig, V., \& Volpin, P. (2015). Labor Protection and Leverage. The Review of Financial Studies, 28(2), 561-591. https://doi.org/10.1093/rfs/hhu053.

5. Belkhira, M., \& Ben-Nasr, H. (2016). Labor protection and the privatization or partial privatization method. International Review of Economics \& Finance, 44, 305-322. https://doi. org/10.1016/j.iref.2016.02.008.

6. Voloshyna, S. M. (2015). Concept of occupational safety and health. Naukovyy visnyk Uzhhorods'koho Natsional'noho universytetu. Seriya: Pravo, 35 (Ch. 1, T. 2), 48-51.

7. The Labor Code of Ukraine (2019). New version of June 21, 2019. Retrieved from https://zakon.rada.gov.ua/laws/ show/322-08.

8. The Law of Ukraine "On Mandatory State Social Insurance against Industrial Accident and Occupational Disease that Caused Disability" (2014). New version of April 1, 2014. Retrieved from https://zakon.rada.gov.ua/laws/show/1105-14/ed20140419.

9. Dreval, Yu. D. (2018). The problem of the concept and categorial apparatus in the field of labor safety. Collection of scientific works of KhNPU named after G. S. Skovoroda "law", (28), 15-20. https://doi.org/10.5281/zenodo.1316976.
10. The Constitution of Ukraine (2019). New version of February 21, 2019. Retrieved from https://zakon.rada.gov.ua/laws/ show $/ 254 \%$ D0\%BA/96-\%D0\%B2\%D1\%80.

11. The Law of Ukraine "On Adopting the National Social Program for Improvement of Safety, Workplace Hygiene and Production Environment in 2014-2018" (2015). New version of January 1, 2015. Retrieved from https://zakon.rada.gov.ua/ laws/show/178-18.

12. Smirnov, G., \& Odintsova, A. (2019). "Homo Nooeconomicus" as a Human Image for the Noospheric Epoch. Future Human Image, 11, 91-97. https://doi.org/10.29202/ fhi $/ 11 / 10$.

13. Rudenko, S., Bazaluk, O., Tsvykh, V., \& Kalmuk, I. (2019). The Role of Philosophical Disciplines in Educational Strategies for Specialist Training in the Field of Public Administration. Naukovyi Visnyk Natsionalnoho Hirnychoho Universytetu, (3), 158-163. https://doi.org/10.29202/nvngu/2019-3/22.

14. Kyvliuk, O., Polishchuk, O., Svyrydenko, D., \& Yatsenko, O. (2018). Educational management as education diplomacy: strategies for Ukraine. Naukovyi Visnyk Natsionalnoho Hirnychoho Universytetu, (3), 139-144. https://doi. org/10.29202/nvngu/2018-3/23.

15. European Agency for Safety and Health at Work (2019). Retrieved from https://osha.europa.eu/en.

16. EU Strategic Framework on Health and Safety at Work 2014-2020 (2019). Retrieved from https://eur-lex.europa.eu/ legal-content/EN/TXT/?uri=COM:2014:332:FIN.

17. International Labour Organization (ILO) (2019). Retrieved from https://www.ilo.org/global/lang--en/index.htm.

18. World Health Organization (WHO) (2019). Retrieved from https://www.who.int/.

19. Bazaluk, O. (2019). The Revival of the Notion of Arete in Contemporary Philosophy. Schole, 13.1, 198-207. https://doi. org/10.25205/1995-4328-2019-13-1-198-207.

20. Khyzhna, O., \& Lendiel-Siarkevych, A. (2018). Peace Education as Arts Education: In Search of New Strategies. Philosophy and Cosmology, 21, 74-83. https://doi. org/10.29202/phil-cosm/21/8.

21. Lavrysh, Yu. (2018). Implementation of Transformative Sustainability Learning into Engineering Curricular. Future Human Image, 9, 63-73. https://doi.org/10.29202/fhi/9/6.

22. Svyrydenko, D., \& Możgin, W. (2019). The Condition of Contemporary Ukrainian Culture: The Postcolonial Retrospective and Perspective. Ukrainian Policymaker, 4, 43-51. https://doi.org/10.29202/up/4/7.

\section{Правове регулювання охорони праці в Свропейському Союзі та Україні: компаративістський підхід}

\section{В. О. Заросило ${ }^{1}$, О. В. Фатхутдінова ${ }^{2}$, T. В. Морозовська ${ }^{1}$, Т. Б. Аріфходжсаєва ${ }^{1}$, Г.М. Строганова}

1 - Міжрегіональна академія управління персоналом, м. Київ, Україна, e-mail: zarosi@ukr.net

2 - Київський університет туризму, економіки і права, м. Київ, Україна

3 - Національний педагогічний університет імені М. П. Драгоманова, м. Київ, Україна

Мета. Використати можливості компаративістського підходу для дослідження відповідності правового регулювання охорони праці в державах Європейського Союзу та України, а також з урахуванням отриманих результатів сформулювати стратегію розвитку законодавчої бази з охорони праці в Україні.

Методика. Своє дослідження автори побудували на можливостях компаративістського підходу. В якості 
основних були використані два принципи: а) принцип сумісності явищ, інститутів і установ; б) принцип відповідності один одному різних рівнів, форм і видів елементів порівнюваних систем.

Результати. Автори розглянули можливості компаративістського підходу, за допомогою якого порівняли смисли терміну „охорона праці“ в Україні та Європейському союзі. Автори довели їх невідповідність, а також необхідність відмовитися від використання терміна „охорона праці“ на користь терміна „Occupational safety and health", що використовується в законах і нормативно-правових документах Європейського Союзу. Автори сформулювали основні напрямки нової стратегії правового регулювання охорони праці в Україні.

Наукова новизна. Використання компаративістського підходу при розгляді відповідності правового регулювання охорони праці в державах Європейського Союзу та України дозволило:

1. Довести необхідність заміни терміна „охорона праці“ терміном „Осcupational safety and health“ („безпека i гігієна праці“"), що використовується в законах і нормативно-правових документах Європейського Союзу.

2. Сформулювати стратегію розвитку законодавчої бази з охорони праці в Україні для іії адаптації до фундаментальних принципів, узаконених Європейським Парламентом.

Практична значимість. Отримані результати дослідження розвивають законодавчу базу з охорони праці в Україні, а також адаптують її під ключові директиви, керівні принципи та стандарти Європейського Союзу, Організації Об'єднаних Націй, Всесвітньої організації охорони здоров'я, Міжнародної організації праці та інших авторитетних міжнародних організацій та інституцій. Дослідження усуває юридичну колізію, що склалася в українському законодавстві з охорони праці, яка порушує роботу правової системи та обмежує права громадян.

Ключові слова: охорона праці, безпека і гігієна праці, правове регулювання, Украӥна, Європейський союз, компаративістський підхід, правова освіта

\section{Правовое регулирование охраны труда в Европейском Союзе и Украине: компаративистский подход}

\author{
В. А. Заросило ${ }^{1}$, Е. В. Фатхутдинова ${ }^{2}$, \\ Т. В. Морозовская ${ }^{1}$, Т. Б. Арифходжсаева ${ }^{1}$, \\ А. Н. Строганова ${ }^{3}$
}

1 - Межрегиональная академия управления персоналом, г. Киев, Украина, e-mail: zarosi@ukr.net

2 - Киевский университет туризма, экономики и права, г. Киев, Украина

3 - Национальный педагогический университет имени М. П.Драгоманова, г. Киев, Украина
Цель. Использовать возможности компаративистского подхода для исследования соответствия правового регулирования охраны труда в государствах Европейского Союза и Украины, а также на основе полученных результатов сформулировать стратегию развития законодательной базы по охране труда в Украине.

Методика. Свое исследование авторы построили на возможностях компаративистского подхода. В качестве основных были использованы два принципа: а) принцип сопоставимости явлений, институтов и учреждений; б) принцип соответствия друг другу различных уровней, форм и видов элементов сравниваемых систем.

Результаты. Авторы рассмотрели возможности компаративистского подхода, с помощью которого сравнили смыслы термина „охрана труда“ в Украине и Европейском союзе. Авторы доказали их несоответствие, а также необходимость отказаться от использования термина „охрана труда“ в пользу термина „Occupational safety and health“, который используется в законах и нормативно-правовых документах Европейского Союза. Авторы сформулировали основные направления новой стратегии правового регулирования охраны труда в Украине.

Научная новизна. Использование компаративистского подхода при рассмотрении соответствия правового регулирования охраны труда в государствах Европейского Союза и Украины позволило:

1. Доказать необходимость замены термина „охрана труда“ термином „Осcupational safety and health“ („безопасность и гигиена труда“), который используется в законах и нормативно-правовых документах Европейского Союза.

2. Сформулировать стратегию развития законодательной базы по охране труда в Украине для её адаптации к фундаментальным принципам, узаконенным Европейским Парламентом.

Практическая значимость. Полученные результаты исследования развивают законодательную базу по охране труда в Украине, а также адаптируют её под ключевые директивы, руководящие принципы и стандарты Европейского Союза, Организации Объединенных Наций, Всемирной организации охраны здоровья, Международной организации труда, и других авторитетных международных организаций и институтов. Исследование устраняет юридическую коллизию, сложившуюся в украинском законодательстве по охране труда, которая нарушает работу правовой системы и ущемляет права граждан.

Ключевые слова: охрана труда, безопасность и гигиена труда, правовое регулирование, Украина, Европейский союз, компаративистский подход, правовое образование

Recommended for publication by N. P. Bortnyk, Doctor of Juridical Sciences. The manuscript was submitted 06.01.19. 